日耳鼻 $105 ： 178-187,2002$

\begin{abstract}
別府武
鎌田 信悦

川端 一嘉

苦瓜 知彦

保喜 克文

三谷 浩樹

吉本 世一
\end{abstract}

癌研究会附属病院頭頸科
耳下腺癌における頸部郭清術の方針についての検討

1975年から1995年までに当科で根治手術を施行した原発性耳下腺癌 1 次例 45 症 例を対象として頸部郭清の術式と治療成績の結果をもとに頸部郭清術の方針につ いて検討した。術前頸部リンパ節転移を認めた症例（以下 $N(+)$ 群）は14例で全 例高悪性度癌であった。これらには全例患側の全頸部郭清を施行し, 頸部再発を 認めたのは郭清辺縁再発の1例のみであった。また，術前頸部リンパ節転移を認 めなかった症例 (以下 $N(-)$ 群) は31例で低悪性度癌 9 例, 高悪性度癌22例であっ た. 予防的郭清を施行しなかった27例には高覀性度癌36例中19例が，また T3ない しは T4 症例 24 例中12例が合まれていたが, 後発転移をきたしたのは 2 例 (7.4\%) のみであった。しかし，初回手術後原発巣が制御できているにもかかわらず頸部 転移をきした症例は全頸部に転移が分布していることが多く，その予後は非常 に不良であった，潜在的頸部りンパ節転移陽性例を予測する手段として腫腸の組 織型を診断することは重要と考えられたが，穿刺吸引細胞診での組織診断率は $21.8 \%$ 現時点では困難と考えられた。しかし, 病理学的転移陽性例の全例で jugulodigastric nodeへの転移が認められたことより，このリンパ節の術中病理 検索が有用と考元られた。また，病理学的転移陽性例における転移りンパ節は全 頸部に分布していた，以上から耳下腺癌に対する頸部郭清術の方針について我々 は以下のように考えた．1． N(+)群では患側の全頸部郭清術を行うべきである。 2. $\mathrm{N}($ (一)群では基本的に予防的頸部郭清術を行う必要はないが, jugulodigastric node の術中迅速病理検查で転移陽性であれば, 全頸部郭清術を行うべきである.

キーワード: 耳下腺癌, 頸部郭清, 予防的郭清, jugulodigastric node

\section{はじめに}

耳下腺癌において頸部リンパ節転移の有無が重要な予 後因子であることは既に広く知られている年231. した がって頸部リンパ節制御のための頸部郭清術は，治療上 重要な位置を占めると考えられる。しかし， $\mathrm{N}(+)$ 群に おける健側の頸部郭清術の必要性や，N(一)群における 予防的郭清の適応などについてはいまだ一定の基準が示 されていない(2)5)6).今回我々は, 耳下腺癌自験例において 頸部郭清術の術式と治療結果をもとに頸部郭清術の方針 について検討したので報告する。

\section{対 象}

1975年から1995年までに当科で根治手術を施行した原 発性耳下腺癌 1 次例 45 症例を対象とした. その内訳は男 性27例 (49歳～79歳, 平均61.3歳), 女性18例 (14歳 85
歳, 平均 56.4 歳), 術後の平均経過観察期間は61.6力月( 3 力月一 246 力月)であった. 今回各症例の切除標本を病理 学的に再検鏡したが, 全症例の組織型別, 病理学的悪性 度別症例数を表 1 に示す．また，TN 分類を表 2 に示す。 腫瘍の病理組織学的分類は1991年度 WHO 分類 ${ }^{7} に$, TN 分類は1997年度 UICC 分類 ${ }^{8)}$ に準じた。な拉術前の 頸部リンパ節転移の評価は主に触診により判断し, 症例 によっては CT, MRI のいずれかないしはこれらを組み 合わせて補助的に診断した。

\section{方法}

これら45症例について以下の事項を検討した.

1. $\mathrm{N}(+)$ 群， $\mathrm{N}($ (一)群それぞれにおける疾患特異的 累積 5 年生存率, 10 年生存率, および原病死症例の死因, 術後生存期間 
表 1 全症例の組織型, 病理学的悪性度別の内訳

\begin{tabular}{|c|c|c|c|c|}
\hline & \multicolumn{2}{|c|}{ 組織型（略記） } & \multicolumn{2}{|c|}{ 症例数 } \\
\hline \multirow{4}{*}{ 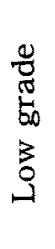 } & 腺房細胞癌 & (Acinic) & 2 & \multirow{4}{*}{9} \\
\hline & 基底細胞癌 & (Basal cell adenoca) & 2 & \\
\hline & 上皮性筋上皮癌 & (Epithe. myo) & 1 & \\
\hline & 粘表皮癌 & (Muco (low)) & 4 & \\
\hline \multirow{8}{*}{ 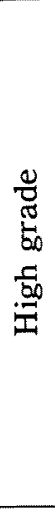 } & 腺様襄胞癌 & $(\mathrm{ACC})$ & 7 & \multirow{8}{*}{36} \\
\hline & 腺癌(not otherwise specified) & (Adeno NOS) & 3 & \\
\hline & 多形性腺腫内癌 & $(\mathrm{Ca}$ in $\mathrm{PA})$ & 8 & \\
\hline & 粘表皮癌 & (Muco (high)) & 11 & \\
\hline & Oncocytic carcinoma & (Oncocytic ca) & 1 & \\
\hline & Salivary duct carcinoma & (Saliv. duct ca) & 1 & \\
\hline & 扁平上皮癌 & $(\mathrm{SCC})$ & 2 & \\
\hline & 末分化癌 & (Undiff ca) & 3 & \\
\hline \multicolumn{3}{|c|}{ 計 } & \multicolumn{2}{|c|}{45} \\
\hline
\end{tabular}

表 2 全症例の TN 分類

\begin{tabular}{|l|rccccc|r|}
\hline & N0 & N1 & N2a & N2b & N2c & N3 & 計 \\
\hline T1 & 7 & 0 & 0 & 1 & 0 & 0 & 8 \\
T2 & 9 & 1 & 0 & 2 & 1 & 0 & 13 \\
T3 & 10 & 1 & 0 & 1 & 0 & 0 & 12 \\
T4 & 5 & 4 & 0 & 3 & 0 & 0 & 12 \\
\hline 計 & 31 & 6 & 0 & 7 & 1 & 0 & 45 \\
\hline
\end{tabular}

原病死の死因に関しては，死亡時に原発巣再発を認め た場合は原発死，原発巣制御がなされていて頸部再発を 認めれば頸部死，原発巣と頸部の制御がなされているに もかかわらず，遠隔転移を認めれば遠隔死と定義した。

2. 低悪性度癌, 高悪性度癌それぞれの $\mathrm{N}(+)$ 群， N (一)群における疾患特異的累積 5 年生存率, 10 年生存率, および原病死症例の死因，術後生存期間

3. $N(+)$ 群における術後頸部再発の状況

4. $N($ (一)群における術後頸部再発の状況

5. 頸部再発または後発転移症例の転帰

6. 穿刺吸引細胞診と最終病理組織診断の比較 穿刺吸引細胞診にて Class 1，2，3 までを良性診断， Class 4,5 を悪性診断と分類した。

7. 病理学的頸部リンパ節転移陽性例における郭清野 別転移率, 転移リンパ節の個数

なお, 生存率は Kaplan-Meier 法を使用して算出し, 統計学的有意差の検討には Log-rank 法, 一般化 Wil- coxon 法を用いた．また，頸部りンパ節群の分類は1991 年の AAO-HNSによる取り扱い規約9)にしたがった。

\section{結果}

1. $\mathrm{N}(+)$ 群， $\mathrm{N}($ (一)群それぞれに招ける疾患特異的 累積 5 年生存率, 10 年生存率扝よび原病死例の死因, 術 後生存期間について（表 3, 図 1)

$\mathrm{N}(+)$ 群の疾患特異的累積 5 年生存率, 10 年生存率は ともに7.7\%であった。これに対してN(一)群ではそれそ れ70.2\%，56.0\%で有意に予後良好であった $(\mathrm{p}<0.0001)$.また, 原病死例の死因の内訳は $\mathrm{N}(+)$ 群で 原病死 12 例中原発死 6 例, 頸部死 1 例, 遠隔死 5 例, $\mathrm{N}$ (一)群では原病死11例中原発死 5 例, 頸部死 1 例, 遠隔 死 5 例であった。一方, 術後の平均生存期間は $\mathrm{N}(+)$ 群 の原発死13.5力月, 頸部死17.0力月, 遠隔死20.4力月, $\mathrm{N}$ (一)群の原発死47.0力月, 頸部死51.0力月, 遠隔死 24.8 カ月であった。

2. 低悪性度癌, 高悪性度癌それぞれの $\mathrm{N}(+)$ 群, $\mathrm{N}$ (一)群に扝ける疾患特異的累積 5 年生存率, 10 年生存率, および原病死症例の死因, 術後生存期間（表 4, 図 2)

低悪性度癌症例は全例で頸部りンパ節転移を認めな かった。低悪性度癌の疾患特異的累積 5 年生存率, 10 年 生存率はともに $88.9 \%$ であり，高悪性度癌の 5 年生存率 $41.9 \%, 10$ 年生存率30.3\%に比して有意に良好であった $(\mathrm{p}<0.01)$. しかし, 高覀性度癌症例を $\mathrm{N}(+)$ 群, $\mathrm{N}(-)$ 群に分けてみると $N(+)$ 群の疾患特異的累積 5 年生存率 
表 $3 \mathrm{~N}(-)$ 群， $\mathrm{N}(+)$ 群における疾患特異的累積生存率，原病死例の死因，術後生存期間

\begin{tabular}{|c|c|c|c|c|c|c|c|c|}
\hline & \multirow{2}{*}{ 症例数 } & \multicolumn{2}{|c|}{ 疾患特異的生存率（\%） } & \multirow{2}{*}{$\begin{array}{l}\text { 術後 } 10 \text { 年 } \\
\text { にお け } \\
\text { 原病死者数 }\end{array}$} & \multicolumn{3}{|c|}{ 死因別死者数と術後平均生存期間 (月) } & \multirow{2}{*}{$\begin{array}{l}\text { 非原病死 } \\
\text { または死因 } \\
\text { 不明者数 }\end{array}$} \\
\hline & & 術後 5 年 & 術後 10 年 & & 原発死 & 頸部死 & 遠隔死 & \\
\hline$N(-)$ 群 & 31 & 70.2 & 56.0 & 11 & $5(47.0)$ & $1(51.0)$ & $5(24.8)$ & 2 \\
\hline $\mathrm{N}(+)$ 群 & 14 & 7.7 & 7.7 & 12 & $6(13.5)$ & $1(17.0)$ & $5(20.4)$ & 1 \\
\hline 全症例 & 45 & 51.7 & 41.9 & 23 & $11(28.7)$ & $2(34.0)$ & $10(22.6)$ & 3 \\
\hline
\end{tabular}

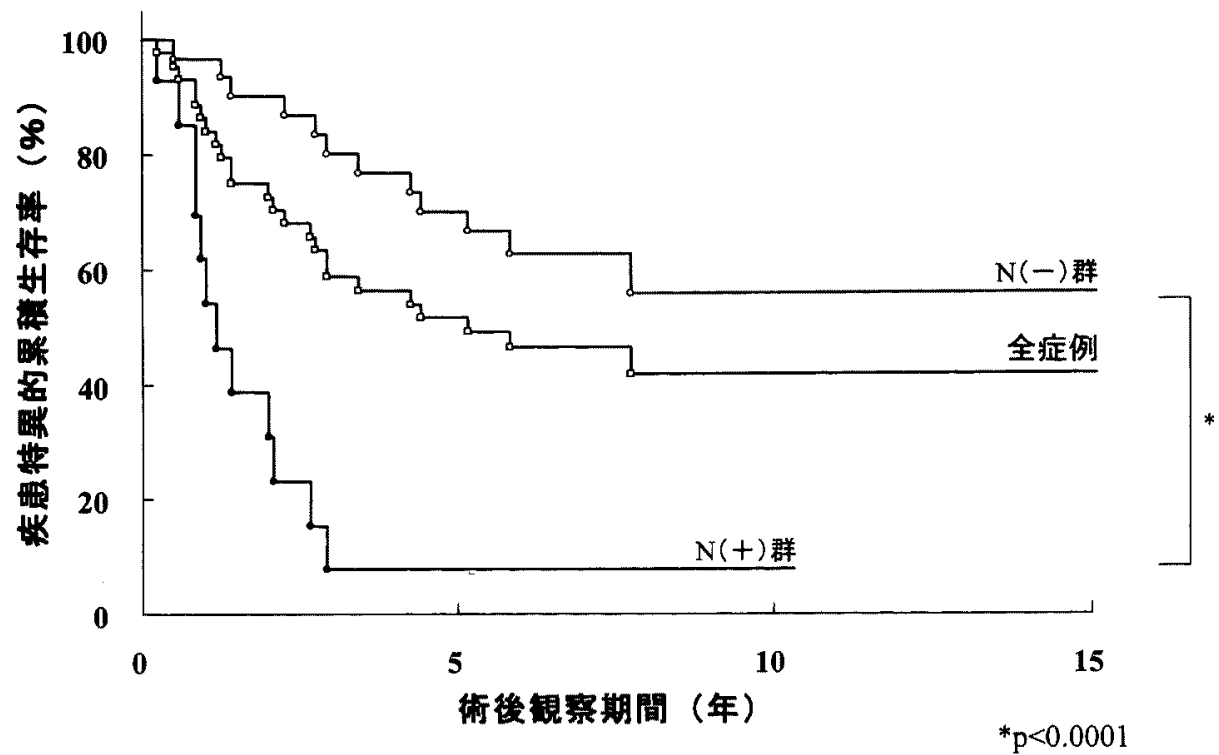

図 $1 \mathrm{~N}($ ( ) 群, $\mathrm{N}(+)$ 群における疾患特異的累積生存率

表 4 低悪性度㿋, 高悪性度癌 $\mathrm{N}($ ( ) 群, $\mathrm{N}(+)$ 群における疾患特異的累積生存率, 原病死例の死因, 術後生存期間

\begin{tabular}{|c|c|c|c|c|c|c|c|c|c|c|c|c|}
\hline & \multirow{2}{*}{\multicolumn{2}{|c|}{ 症例数 }} & \multicolumn{4}{|c|}{ 疾患特異的生存率 (\%) } & \multirow{2}{*}{$\begin{array}{c}\text { 術後 } 10 \text { 年 } \\
\text { における } \\
\text { 原病死者数 }\end{array}$} & \multicolumn{3}{|c|}{ 死因別死者数と術後平均生存期間 (月) } & \multirow{2}{*}{$\begin{array}{c}\text { 非原病死 } \\
\text { または死因 } \\
\text { 不明者数 }\end{array}$} \\
\hline & & & & \multicolumn{2}{|c|}{ 術後 5 年 } & \multicolumn{2}{|c|}{ 術後10年 } & & 原発死 & 頸部死 & 遠隔死 & \\
\hline$\frac{4}{4+4}$ & $\begin{array}{c}\text { 低悪性度癌 } \\
\mathrm{N}(-) \text { 群 }\end{array}$ & 9 & \multirow{2}{*}{9} & 88.9 & \multirow{2}{*}{88.9} & 88.9 & \multirow{2}{*}{88.9} & 1 & 0 & 0 & $1(41.0)$ & 0 \\
\hline 萧 & $\begin{array}{c}\text { 低悪性度癌 } \\
N(+) \text { 群 }\end{array}$ & 0 & & & & & & & & & & \\
\hline \multirow{2}{*}{ 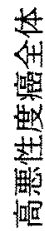 } & $\begin{array}{c}\text { 高覀性度癌 } \\
N(-) \text { 群 }\end{array}$ & 22 & \multirow{2}{*}{36} & 62.4 & \multirow{2}{*}{41.9} & 43.2 & \multirow{2}{*}{30.3} & 10 & $5(36.9)$ & $1(51.0)$ & $4(20.8)$ & 2 \\
\hline & $\begin{array}{c}\text { 高覀性度癌 } \\
N(+) \text { 群 }\end{array}$ & 14 & & 7.7 & & 7.7 & & 12 & $6(13.5)$ & $1(17.0)$ & $5(20.4)$ & 1 \\
\hline
\end{tabular}

$7.7 \%, 10$ 年生存率 $7.7 \%$ に比してN(一)群では 5 年生存 率62.4\%, 10年生存率 $43.2 \%$ ありり，有意に良好であっ た $(\mathrm{p}<0.0005)$ 。また, 低悪性度癌と高悪性度癌 $\mathrm{N}(-)$ 群の間で疾患特異的累積生存率に統計学的有意差は認め
られなかった。一方，原病死例の死因の内訳は高悪性度 癌 $N(+)$ 群で原病死 12 例中原発死 6 例, 頸部死 1 例, 遠 隔死 5 例, 高悪性度癌 $N(-)$ 群では原病死10例中原発死 5 例, 頸部死 1 例, 遠隔死 4 例であった. 術後の平均生 


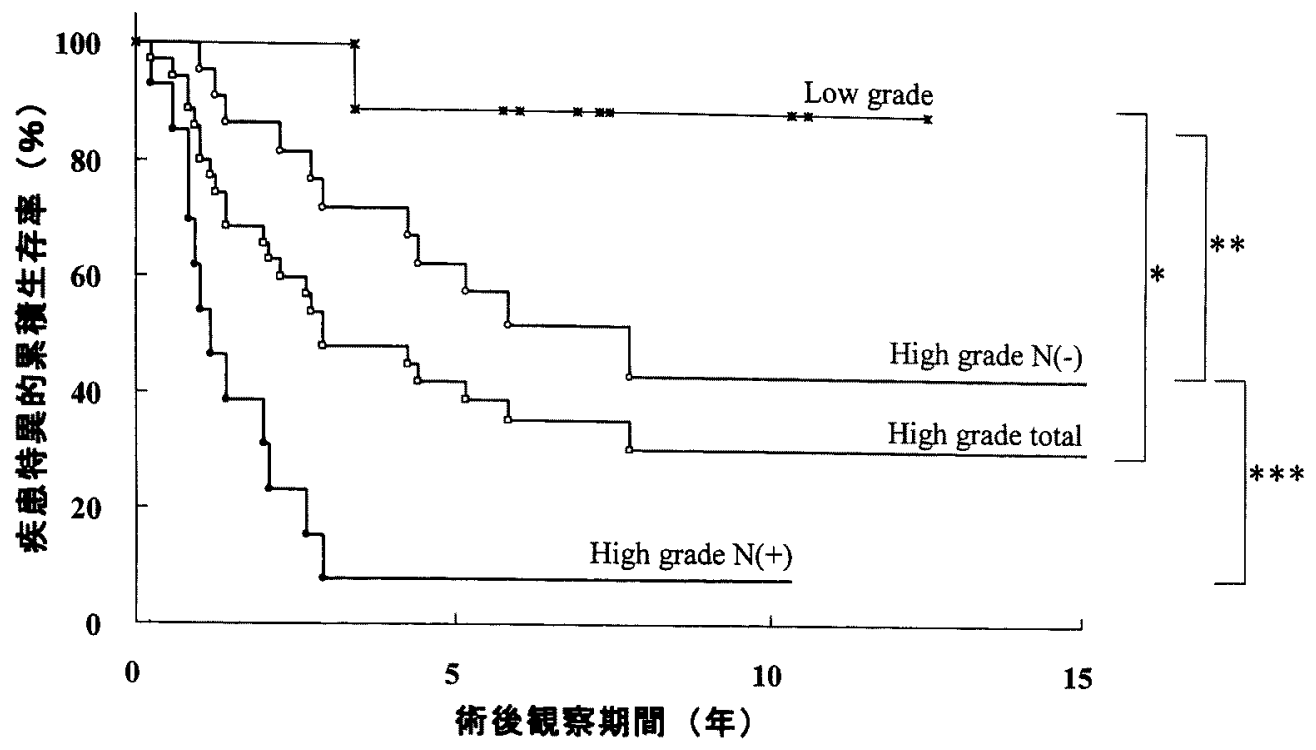

${ }^{*} \mathrm{p}<0.01,{ }^{* *}$ 有意差なし, ${ }^{* * *} \mathrm{p}<0.0005$

図 2 低悪性度癌, 高悪性度癌に抢ける疾患特異的累積生存率

表 $5 \mathrm{~N}(+)$ 群における術後頸部再発の状況

\begin{tabular}{|c|c|c|c|c|}
\hline 郭清術式 & 症例数 & $\begin{array}{l}\text { 患側頸部リンパ節 } \\
\text { 病理学的転移陽性例 }\end{array}$ & 頸部再発例 & $\begin{array}{l}\text { 原発巣が制御されていて } \\
\text { 頸部再発を認めた症例 }\end{array}$ \\
\hline 選択的頸部郭清 & 0 & & & \\
\hline 全頸部郭清 & 14 & 14 & $\begin{array}{c}1 \\
T 1, \text { Muco (high) }\end{array}$ & $\begin{array}{c}1(7.1 \%) \\
\text { T1, Muco(high) } \\
\text { 患側 Level V (郭清野辺縁) に再発 }\end{array}$ \\
\hline
\end{tabular}

存期間は高悪性度癌 $\mathrm{N}(+)$ 群で原発死13.5力月, 頸部死 17.0力月, 遠隔死 20.4 力月, 高悪性度癌 $\mathrm{N}(-)$ 群で原発 死36.9力月, 頸部死51.0力月, 遠隔死20.8力月であった.

3. $N(+)$ 群における術後頸部再発の状況（表 5 )

$\mathrm{N}(+) 14$ 例全例に対して全頸部郭清を行った。頸部再 発を怹めたのは T1の高悪性度粘表皮癌 1 例 (7.1\%) の みであり，この症例では原発巣は制御されていた．再発 部位は患側レベル Vの後緑であり, 郭清野辺緑再発で あった。

4. $\mathrm{N}($ (一)群に扔ける術後頸部再発の状況 (表 6, 7) $\mathrm{N}(-$ )群31症例中 4 例に予防的頸部郭清（選択的頸部 郭清 2 例, 全頸部郭清 2 例）を施行し，残りの27例は原 発巣に対する手術のみを施行した。この 27 例における組 織型分類， T分類を表 6 に示す。予防的頸部郭清を施行 しなかった27例のうち頸部再発をきたしたのは 5 例あっ たが，原発巣が制御されているにもかかわらず頸部に再 発をきたした，いわゆる後発転移例は T1 の腺癌，T3の 腺房細胞癌の 2 例 $(7.4 \%)$ であった. 再発部位は T1の 腺潞で患側のレベル I, II, III, IV, V, T3 の腺房細胞
表 6 予防的郭清術を行わなかった症例の組織型, $\mathrm{T}$ 分類

\begin{tabular}{|c|c|c|c|c|c|c|c|}
\hline \multicolumn{2}{|c|}{ 組織型 $\mathrm{T}$ 分類 } & 1 & 2 & 3 & 4 & \multicolumn{2}{|c|}{ 症例数 } \\
\hline \pm & Acinic & 1 & 0 & 1 & 0 & 2 & \\
\hline$\frac{\pi}{2}$ & Basal cell adenoca & 1 & 0 & 0 & 1 & 2 & \\
\hline 3 & Epithe. myo & 0 & 1 & 0 & 0 & 1 & 0 \\
\hline ڤ̊ & Muco & 2 & 1 & 0 & 0 & 3 & \\
\hline \multirow{6}{*}{ 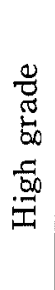 } & ACC & 0 & 1 & 2 & 2 & 5 & \multirow{6}{*}{19} \\
\hline & Adeno NOS & 2 & 0 & 0 & 0 & 2 & \\
\hline & $\mathrm{Ca}$ in $\mathrm{PA}$ & 0 & 2 & 2 & 0 & 4 & \\
\hline & Muco & 1 & 2 & 1 & 1 & 5 & \\
\hline & $\mathrm{SCC}$ & 0 & 0 & 1 & 0 & 1 & \\
\hline & Undiff ca & 0 & 1 & 1 & 0 & 2 & \\
\hline & 計 & 7 & 8 & 8 & 4 & 2 & \\
\hline
\end{tabular}

癌で患側のレベルII, III, Vであった，一方，予防的頸 部郭清を行った 4 例のうち病理学的に転移陽性であった 症例は T3 の未分化癌 1 例のみであった。この症例には 
表 $7 \mathrm{~N}($ (一)群における術後頸部再発の状況

\begin{tabular}{|c|c|c|c|c|c|}
\hline 郭清の有無と術式 & 症例数 & T 分類と組織型 & $\begin{array}{l}\text { 患側頸部リン } \\
\text { パ節病理学的 } \\
\text { 転移陽性例 }\end{array}$ & 頸部再発例 & $\begin{array}{l}\text { 原発巣が制御されていて } \\
\text { 䅡部再発を認めた症例 }\end{array}$ \\
\hline 予防的郭清術 $(-)$ & 27 & 表 6 に記載 & & \begin{tabular}{l}
\multicolumn{1}{c}{5} \\
T1, adeno NOS \\
T3, acinic \\
T4, ACC \\
T3, SCC \\
T2, undiff
\end{tabular} & $\begin{array}{l}2(7.4 \%) \\
\text { T1, adeno NOS } \\
\text { 患側 Level I, II, III, } \\
\text { IV, V } \text { 亿再発 } \\
\text { T3, acinic } \\
\text { 患側 Level II, III, V } \\
\text { に再発 }\end{array}$ \\
\hline 予防的郭清術 (+) & 4 & 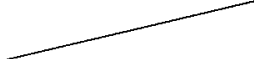 & 1 & 1 & 1 \\
\hline \multirow{2}{*}{ 選択的頸部郭清術 } & Level I & T3, undiff & \multirow{2}{*}{$\begin{array}{c}1 \\
\text { T3, undiff }\end{array}$} & \multirow{2}{*}{$\begin{array}{c}1 \\
\mathrm{~T} 3, \text { undiff }\end{array}$} & \multirow{2}{*}{$\begin{array}{l}1 \\
\text { T3, undiff } \\
\text { 患側 Level II, III, IV, } \\
\text { Vに再発 }\end{array}$} \\
\hline & Level I, II & T3, Muco (low) & & & \\
\hline 全頸部郭清術 & 2 & $\begin{array}{l}\text { T4, ACC } \\
\text { T2, ACC }\end{array}$ & 0 & 0 & 0 \\
\hline
\end{tabular}

表 8 原発巣が制御されているにもかかわらず頸部再発を网めた症例の転帰, 死因, 術後生存期間

\begin{tabular}{|c|c|c|c|c|c|}
\hline $\begin{array}{l}\text { TN 分類 } \\
\text { 組織型 }\end{array}$ & $\begin{array}{l}1 \text { 次治療として } \\
\text { の頸部郭清術式 } \\
\text { と郭清範囲 }\end{array}$ & $\begin{array}{l}\text { 患側頸部 } \\
\text { 転移陽性 } \\
\text { リンパ節 } \\
\text { 個数 }\end{array}$ & 転帰 & 死因 & $\begin{array}{l}\text { 初回手術後加 } \\
\text { の生存期間(月) }\end{array}$ \\
\hline $\begin{array}{l}\mathrm{T}_{\mathrm{N}} \mathrm{b}, \\
\text { Muco (high) }\end{array}$ & $\begin{array}{l}\text { 根治的 } \\
\text { 全頸部郭清 }\end{array}$ & 18 & $\begin{array}{l}\text { 術後 } 8 \text { カ月で肺転移. } \\
\text { 術後 } 12 \text { 力月に患側レベルV辺緑に頸部再発. } \\
2 \text { 次治療することなく } \\
\text { 14カ月目に癌性腹膜炎併発. }\end{array}$ & 頸部死 & 17 \\
\hline $\begin{array}{l}\text { T3N0, } \\
\text { Undiff ca }\end{array}$ & $\begin{array}{l}\text { 予防的選択的 } \\
\text { 頸部郭清 } \\
\text { (レベルIのみ) }\end{array}$ & 1 & $\begin{array}{l}\text { 術後 } 4 \text { カ月で患側レベル II, III, IV, VR } \\
\text { 頸部再発. } \\
\text { 患側の頸部郭清を行うも } 5 \text { 力月目に肺転移. }\end{array}$ & 遠隔死 & 6 \\
\hline $\begin{array}{l}\text { T1N0, } \\
\text { Adeno NOS }\end{array}$ & \multicolumn{2}{|c|}{ 頸部郭清せず } & $\begin{array}{l}\text { 術後10カ月で患側レベル I, II, III, IV, V } \\
\text { に頸部再発. } \\
\text { 患側の頸部郭清を行うも頸部制御不能. }\end{array}$ & 頸部死 & 50 \\
\hline $\begin{array}{l}\text { T3N0, } \\
\text { Acinic }\end{array}$ & \multicolumn{2}{|c|}{ 頸部郭清せず } & $\begin{array}{l}\text { 術後12力月で患側レベル II, III, V V頸部再 } \\
\text { 発. 患側の頸部郭清を行うも，29力月目に肺 } \\
\text { 転移，35力月目に皮䖉転移。 }\end{array}$ & 遠隔死 & 41 \\
\hline
\end{tabular}

頢下部のみの選択的頸部郭清術が施行されていたが, 原 発巣制御がなされていたにもかかわらず患側のレベル II, III, IV，Vの郭清野外に頸部再発を認めた.

5. 頸部再発または後発転移症例の転帰（表 8)

初回手術で原発巣に対する手術に加えて頸部郭清術を 施行し, 原発巣が制御されているにもかかわらず後に頸 部再発を認めた 2 例と初回手術で原発巣に対する手術の
みを施行し，原発巣が制御できているにもかかわらず後 に頸部に転移をきたした 2 例についての転㷌, 死因, 術 後生存期間を表 8 に示す. 4 例のうち 1 例は頸部再発の 時点で既に遠隔転移を認めたため 2 次治療することなく 死亡したが，残りの 3 例には 2 次治療として患側の頸部 郭清術が施行されていた。しかし，頸部制御がなされな いまま死亡した例が 1 例，後に遠隔転移をきたし死亡し 
た例が 2 例といずれも予後は極めて不良であった。

6. 穿刺吸引細胞診と最終病理組織診断の比較(表 9) 穿刺吸引細胞診 (FNAC) 未施行の11例と検体が不良 であった 2 例を除く32例について FNAC と最終病理組 織診断の比較を表 9 に示した. FNACで悪性診断がつい たのは32例中23例で悪性診断率は71.9\%であった。さら に組織型までも診断できたのは低悪性度粘表皮癌 1 例， 腺栏蕒胞癌 2 例，腺癌 2 例，高悪性度粘表皮癌 2 例の合 計 7 例であり，組織診断率は21.8\%であった。
7. 病理学的頸部リンパ節転移陽性症例における郭清 野別転移率，転移りンパ節個数（表 10 , 図 3，図 4)

病理学的に頸部リンパ節への転移が陽性であった15症 例における患側の郭清野別転移率は，レベル I：46.7\%， レベルII : 100\%,レベルIII : $85.7 \%$,レベルIV : $50.0 \%$, レベルV $: 57.1 \%$ であり, 全例でレベル II には転移陽性 リンパ節が存在していた，また, 病理学的転移リンパ節 の平均個数は, $\mathrm{N}$ 分類別で $\mathrm{N} 1 ： 3.5$ 個, $\mathrm{N} 2: 15.9$ 個で あった。郭清野別ではレベル I：0.67個,レベル II：3.21

表 9 穿刺吸引細胞診と最終病理組織診断との比較

\begin{tabular}{|c|c|c|c|c|}
\hline & & \multicolumn{2}{|c|}{ 最終病理組織診断 } & \multirow{2}{*}{ 計 } \\
\hline & & 低悪性度癌 & 高悪性度癌 & \\
\hline \multirow{2}{*}{ 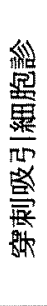 } & $\begin{array}{l}\text { 良性 } \\
\text { (class 1, 2, 3) }\end{array}$ & 5 & 4 & 9 \\
\hline & $\begin{array}{l}\text { 悪性 } \\
\text { (class 4, 5) }\end{array}$ & $\begin{array}{c}3 \\
\text { *Muco(low) } 1\end{array}$ & $\begin{array}{l}\quad 20 \\
{ }^{*} \text { ACC } 2 \\
{ }^{*} \text { Adeno NOS } 2 \\
{ }^{*} \text { Muco (high) } 2\end{array}$ & 23 \\
\hline & 計 & 8 & 24 & $32^{* *}$ \\
\hline
\end{tabular}

*組織診断まで一致した症例 ***細胞診末施行 11 例，検体不良 2 例を除く

表10 病理学的頸部りンパ節転移陽性例

\begin{tabular}{|c|c|c|c|c|c|c|c|c|c|}
\hline \multirow{2}{*}{ 症例 } & \multirow{2}{*}{$\mathrm{T}$ 分類, 組織型 } & \multirow{2}{*}{$\begin{array}{l}\text { 術前の } \\
\mathrm{N} \text { 分類 }\end{array}$} & \multirow{2}{*}{$\begin{array}{l}\text { 患側頸部 } \\
\text { 郭清範囲 }\end{array}$} & \multirow{2}{*}{$\begin{array}{l}\text { 患側頸部転移陽性 } \\
\text { リンパ節個数 }\end{array}$} & \multicolumn{5}{|c|}{ 患側の郭清野別転移陽性リンパ節個数 } \\
\hline & & & & & I & II & III & IV & V \\
\hline 1 & T3 undiff & 0 & I & 1 & 1 & & & & \\
\hline 2 & $\mathrm{~T} 4 \mathrm{Ca}$ in $\mathrm{PA}$ & 1 & $I-V$ & 3 & 1 & 1 & 1 & 0 & 0 \\
\hline 3 & T4 Muco (high) & 1 & $I-V$ & 5 & 0 & 3 & 1 & 1 & 0 \\
\hline 4 & T4 Muco(high) & 1 & $I-V$ & 6 & 0 & 2 & 2 & 0 & 2 \\
\hline 5 & $\mathrm{~T} 2 \mathrm{SCC}$ & 1 & $I-V$ & 1 & 0 & 1 & 0 & 0 & 0 \\
\hline 6 & $\mathrm{~T} 3 \mathrm{Ca}$ in $\mathrm{PA}$ & 1 & $I-V$ & 2 & 0 & 2 & 0 & 0 & 0 \\
\hline 7 & $\mathrm{~T} 4 \mathrm{Ca}$ in $\mathrm{PA}$ & 1 & $I-V$ & 4 & 0 & 3 & 1 & 0 & 0 \\
\hline 8 & $\mathrm{~T} 2 \mathrm{Ca}$ in $\mathrm{PA}$ & $2 b$ & $I-V$ & 25 & 0 & 7 & 9 & 3 & 6 \\
\hline 9 & T1 Muco (high) & $2 \mathrm{~b}$ & $\mathrm{I}-\mathrm{V}$ & 18 & 1 & 6 & 8 & 3 & 0 \\
\hline 10 & T4 Muco (high) & $2 b$ & $I-V$ & 6 & 0 & 3 & 2 & 0 & 1 \\
\hline 11 & T4 Adeno NOS & $2 \mathrm{~b}$ & $I-V$ & 13 & 1 & 5 & 2 & 1 & 4 \\
\hline 12 & T4 Muco(high) & $2 \mathrm{~b}$ & $\mathrm{I}-\mathrm{V}$ & 17 & 2 & 4 & 1 & 0 & 10 \\
\hline 13 & T4 Muco(high) & $2 b$ & $I-V$ & 20 & 0 & 5 & 3 & 3 & 9 \\
\hline 14 & T4 Saliv. duct ca & $2 \mathrm{~b}$ & $I-V$ & 18 & 2 & 2 & 6 & 3 & 5 \\
\hline 15 & T2 Oncocytic ca & $2 c$ & $I-V$ & 10 & 2 & 1 & 1 & 1 & 5 \\
\hline
\end{tabular}




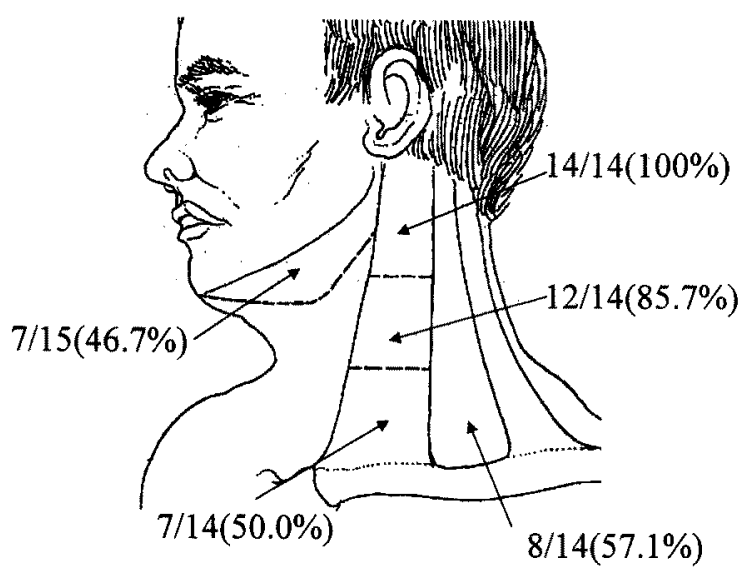

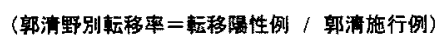

図 3 病理学的頸部リンパ節転移陽性例におけ る郭清野別転移率

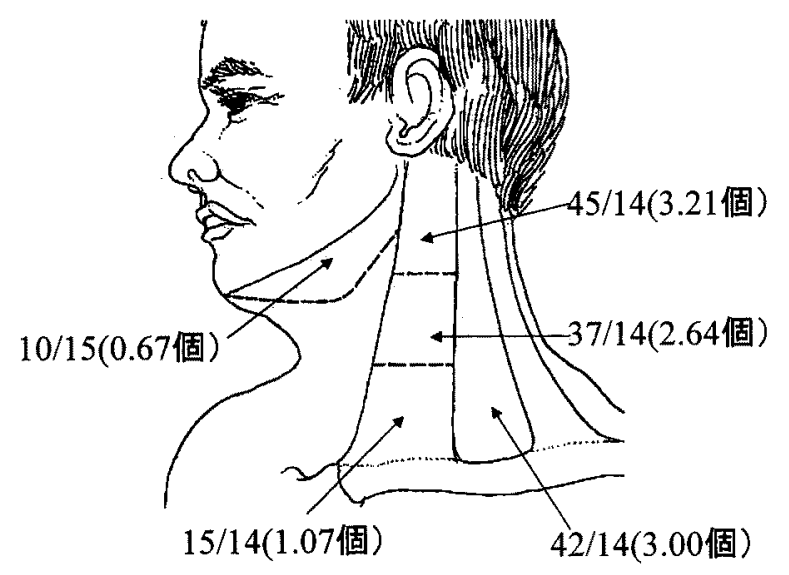

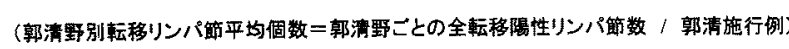

図 4 病理学的頸部リンパ節転移陽性例における郭 清野別転移リンパ節平均個数

個, レベルIII : 2.64個, レベルIV : 1.07個, レベルV : 3 個であった。

\section{考察}

1. $N(+)$ 群の䫓部郭清について

一般に耳下腺癌では初診時にその $20 \%$ 前後に所属リン パ節転移を認める24)10111) とされ，他の頭頸部扁平上皮癌 に比して頻度の高いものではない. しかし，その一方で 諸家が報告するように $\mathrm{N}(+)$ 群での生存率は $\mathrm{N}($ 一) 群の それに比して有意に低いとされる ${ }^{13233)}$.したがって頸部 制御は治療上重要な位置を占めるものと考えられる。当 科においても $\mathrm{N}(+)$ 群は全45例中14例 (31.1\%) であり， その疾患特異的累積 5 年生存率, 10 年生存率はともに $7.7 \%$ と $($ - 群の 5 年生存率 $70.2 \%, 10$ 年生存率 $56.0 \%$
に比して有意に不良であった（ $<<0.0001 ）$.一方，病理 組織学的悪性度も重要な予後因子として広く知られてお $\eta^{1 / 2) 10112113)}$, 今回の検討でも低悪性度癌の疾患特異的累 積 5 年生存率, 10 年生存率はともに $88.9 \%$ あり, 高德 性度癌の 5 年生存率 $41.9 \%, 10$ 年生存率 $30.3 \%$ に比して 有意に良好であった $(\mathrm{p}<0.01)$ 。しかし，高悪性度癌症 例を $\mathrm{N}($ (一) 群と $\mathrm{N}(+)$ 群に分けて検討してみると $\mathrm{N}(-)$ 群の疾患特異的累積 5 年生存率, 10 年生存率はそれぞれ $62.4 \%, 43.2 \%$ であり, $\mathrm{N}(+)$ 群の 5 年生存率 $7.7 \%, 10$ 年生存率 $7.7 \%$ に比して有意に良好であった $(\mathrm{p}<0.0005)$. さらに, 低悪性度癌と高悪性度癌 $N(-)$ 群 の間には生存率に有意差を認めなかった。以上から，䫫 部リンパ節転移の有無は病理学的悪性度以上に強力な予 後因子であると考えられる。原病死例に扔ける死因の検 討では $N(+)$ 群の原病死12例中原発死 6 例, 頸部死 1 例, 遠隔死 5 例, $N(-)$ 群の原病死11例中原発死 5 例, 頸部 死 1 例，遠隔死 5 例であり，この構成比は両群でほは類 似していた。しかしながら，それでれの群での術後平均 生存期間は $\mathrm{N}(+)$ 群の原発死で13.5力月, 頸部死で17.0 力月, 遠嵒死で20.4力月, $N($ 一)群の原発死で47.0力月, 頸部死で51.0力月, 遠隔死で 24.8 力月と大きく異なって いた.このことから， $\mathrm{N}(+)$ 群の予後が悪いのは頸部制 御が困難なのではなく，N(一)群に比して早期に原発栄 再発や遠隔転移をきたす場合が多いためではないかと考 えられた。これらの特徴は高悪性度癌を $\mathrm{N}(+)$ 群と $\mathrm{N}$ (一)群に分けて比較しても全く同様であった. 上述のよ うに当科における頸部制御の成績は比較的良好であり， 死亡例のほとんどが原発巣制御に失敗した場合か, 肺, 骨，肝，皮膚などへ遠隔転移した症例であった．Spiro ら ${ }^{11)}$ は, 耳下腺癌根治術後に原発巣ないしは頸部りンパ 節に再発をきたした症例は39\%であったが，その大部分 は原発单再発を併発しており，頸部再発のみを認めた例

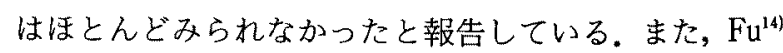
らも原発巣が制御されている場合，頸部再発をきたした ものはわずか $3.5 \%$ あっあたと述べており,我々の結果と 一致するものであった。自験例において $\mathrm{N}(+)$ 群で郭清 術後に頸部再発を認めたのは郭清野辺縁再発の1例 （7.1\%）のみであり，これは郭清野の不足が原因と考え られるものであった。また健側頸部りンパ節への再発を 認めた症例はなかった。以上から頸部リンパ節転移陽性 例の頸部制御に対しては患側の全頸部郭清が必要かつ十 分な術式と考えられた。

2. 予防的郭清の適応と郭清範囲について

一方 N(一)群における予防的郭清の適応や郭清範囲に ついてはいまだ一定の基準が示されていない.これまで 潜在的りンパ節転移の頻度, 後発転移の出現率に関して 
は多くの報告がなされてきた，耳下腺癌全体での潜在的 頻部リンパ節転移率は一般的には10\%程度4)5(6)15)16) とす る報告が多いが，Spiro ら にによれば高悪性度粘表皮癌 て16\%, 腺癌で18\%, epidermoid carcinoma で60\%と高 悪性度癌ではさらに高率であるとする報告も見受けられ る. 自験例の検討でも予防的に頸部郭清を施行したのは 31 例中 4 例（低悪性度癌 1 例, 高悪性度癌 3 例）と少な かったが，そのうちの未分化癌 1 例は病理学的転移陽性 例で後に郭清野外の頸部再発がみられ，施行していない 27例中 2 例に後発転移を認めた。我々はこれまで予防的 郭清を系統的に多数行ってきたわけではないので組織型 や丁病期ごとの潜在的リンパ節転移陽性率を十分検討す ることはできず将来の課題と言えるが，予防的郭清を 行っていない症例が，高悪性度瘟36例中19例 (52.8\%), T分類においても $\mathrm{T} 3$ ないしは $\mathrm{T} 4$ 症例24例中12例 (50.0\%)と決して少なくなかったのにもかかわらず，後 発転移を誌めたのは $\mathrm{T} 1$ の腺癌と T3 の腺房細胞癌の 2 例 (7.4\%) のみであった。以上のように頻度の点から現 時点では予防的郭清は基本的には不要ではないかと考え られた。しかしながら，原発巣が制御されているにもか かわらず，後に頸部再発をきたした症例の転帰を検討し てみると，2 次治療として頸部郭清術を施行しても钼部 制御は容易でなく，その予後は極めて不良であった。し たがって, 後発転移の頻度は低くとも $N($ 一) 群の中から 潜在的頸部リンパ節転移陽性例を術前ないしは術中に判 定する重要性が論じられ，これまでその方法が求められ てきた。

M.D.Anderson Cancer Center $の$ Frankenthaler $ら^{5)}$ は潜在的リンパ節転移を予測する因子を解析し, 顔面神 経麻瘒, 腫瘍の耳下腺外浸潤, 病理学的りンパ管侵襲を あげているが, 最近同施設ではN(+)群のみに䫓部郭清 術を行い，これらの因子陽性例には後治療として術後照 射を追加することにしていると述べている。一方， Memorial Sloan-Kettering Cancer Center $の$ Kelley $ら^{6)}$ は $N($ ( ) 群105例中21例に頸部郭清術を施行しその うち10例が病理学的転移陽性であったが，施行しなかっ た症例で頸部再発を認めたのは 1 例のみであったと報告 しており, 組織型や悪性度を基に予防的郭清を行う症例 を適切に選択することが重要と述べている。また， Califano $5^{47}$ は高墨性度粘表皮癌, 扁平上皮癌, 未分化癌 で䂆防的郭清を行い，その他の組織型ではТ病期の程度 や顔面神経麻盘の有無を参考に症例を選択するとしてい る.

本邦では古くは村上ら ${ }^{13)}$ の腺癌や扁平上皮癌, 腺樣䨳 胞癌, 多形腺腫内癌では原則的に頸部郭清術を行うと いった組織型や悪性度を重視して適応を選択するという
報告や，一方で奥田ら ${ }^{17)}$ のように予防的郭清は行わない とする報告も見受けられる，最近では，組織型と下病期 を組み合わせた適応を述べている報告が多い．安松ら は高悪性度粘表皮癌, 未分化癌の T4 症例では予防的郭

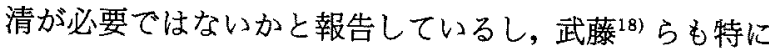
腺癌, salivary duct carcinoma, 扁平上皮癌，未分化癌 では T1であっても頸部郭清を併施すると述べている。 確かに組織型やその悪性度を術前に正確に診断できれば 潜在的頸部リンパ節転移の有無を考慮する上で有効と考 えられる。

当科では術前の病理組織診断を穿刺吸引細胞診 (FNAC)にて判断してきたが，その正診率は覀性診断て $71.9 \%$ ，組織型診断にいたっては $21.8 \%$ にどまってい た.この值は他施設に比して遜色ない結果ではあった が19), 同時に細胞診の限界を示しているとも解釈でき, 必 ずしも満足できる值とはいえない，ただ当科では1996年 より超音波エコーを術前の画像診断の一つに加えてお りエエコー下に狙った部位を穿刺したり，臨床経過や所 見とFNACの結果が一致しない時にもっとすすんで再 検するといった努力をすることでこの值はもう少し向上 する余地があるように考えられる。今回, FNACで悪性 診断がついた23例中20例が病理学的に高悪性度癌であ り，良性と諩断された 9 例中 5 例が低悪性度癌であった。 逆に高悪性度癌24例中20例はFNAC で悪性と䛦断され ており，低悪性度癌 8 例中 5 例が良性と猃断されていた。

Stewart ${ }^{20)}$ は，自験例19例の原発性耳下腺澏の FNAC 検体において14例 (73.7\%) が悪性腫場と診断で きたものの特に低悪性度粘表皮癌と基底細胞癌において は，細胞診断上誤診の可能性があり注意が必要としてい る. Cajulis $ら^{21}$ も同様に腺房細胞癌において異型細胞 が検体内に少ない時, 細胞診では診断が難しいと述べて いる.

以上のことは高悪性度癌では FNACで悪性診断が通 常可能であり, 低悪性度癌では誤診率が高くなること, FNAC で悪性と診断されれば，高悪性度癌のことが多い が低悪性度癌の場合もあること, FNACで良性と診断さ れても高悪性度癌の場合すらあること, FNACで組織診 断までできるのはおよそ20\%にすぎないことを示してい る。したがって，潜在的頸部りンパ節転移陽性例を考慮 する上で組織型を判断材料とするのは, FNAC から術前 の組織診断を求める現時点では困難であるうと思われ る.

一方, Ward $ら^{22)}$ は, 術中の jugulodigastric node の 迅速病理診断によって転移陽性なら頸部郭清を併施する ことを治療ガイドラインとして述べている．また，Ball $ら^{16)}$ は, 術前 $N(+)$ か, 術中の jugulodigastric node の 
迅速病理診断上転移陽性ならば頸部郭清を施行する方針 で40例の耳下腺癌症例に 9 例の頸部郭清を施行し, 頸部 再発を認めた例はなかったと報告している。 Califano ら ${ }^{4)}$ は耳下腺癌のリンパ節転移経路について触れ, 耳下 腺からのリンパ流には深頸部リンパ節への流れ, 後頭部 リンパ節への流れ，顎下部リンパ節への流れの3つがあ るが，媣頸部リンパ節への流れが主流であると述べてい る.

我々は病理学的転移陽性例について郭清野別の転移率 を調べてみたが，レベルII (jugulodigastric node) では 全例陽性であった。また，レベルII, III, IVといった深 頸部リンパ節への流れの他にレベル $\mathrm{V}$ ，特に後頸部リン パ節への流れも転移率で57.1\%, 転移りンパ節の平均個 数として 3 個と無視できない結果であった．臨床的にN (一)である症例において本当に jugulodigastric node に 最初に転移が起こり，潜在的転移陽性例の検出法として このリンパ節の術中病理検索が必要十分であるのかにつ いては今後の研究が必要であるが, jugulodigastric node は原発巣の手術と同一術野で採取が可能であるうえに, 今回少なくとも病理学的転移陽性例においてはレベル II への転移率が $100 \%$ であったこと, 転移陽性リンパ節の分 布はレベルI からレベルVまでの全頸部に認められたこ と, 頸部郭清を施行しなかった群で後発転移をきたした 例での再発部位はほぼ全頸部に及んでいたことから，現 時点では予防的頸部郭清の適応を決める上で jugulodigastric nodeの術中病理検索が有用であると考 えられ，その結果転移陽性であれば全頸部郭清を行い, 転移陰性であれば郭清を行わないという方針が妥当では ないかと考えられた。

\section{結 論}

当科に扔いて過去21年間に治療した原発性耳下腺癌根 治術施行 1 次例について㭘討し, 耳下腺癌に対する頸部 郭清術の治療方針として次の 2 点を結論づけた.

1. 術前頸部リンパ節転移陽性である症例では患側の 全頸部郭清術を行うべきである。

2. 術前頸部リンパ節転移を認めない症例では基本的 に予防的頸部郭清術を行う必要はないが, jugulodigastric node の術中迅速病理検査で転移陽性であれば, 全頸 部郭清術を行い, 転移を認めなければ頸部郭清術は行わ ない.

\section{文献}

1) Therkildsen $\mathrm{MH}$, Christensen $M$, Andersen LJ, Schiodt T, Hansen HS: Salivary gland carcinomas -prognostic factors-. Acta Oncologica 37 : 701-713, 1998.
2) Spiro RH, Huvos AG, Strong EW : Cancer of the parotid gland. -A clinicopathologic study of 288 primary cases-. Am J Surg 130: 452-459, 1975.

3）安松隆治，一番ヶ瀬 崇, 富田和英, 原崇, 末田尚 之, 他: 耳下腺癌の臨床的検討. 日耳鼻 102：883$890,1999$.

4) Califano L, Zupl A, Massari PS, Giardino C: Indication for neck dissection in carcinoma of the parotid gland. our experience on 39 cases. Int Surg 78:347349, 1993.

5) Frankenthaler RA, Byers RM, Luna MA, Callender DL, Goepfert PWH : Predicting occult lymph node metastasis in parotid cancer. Arch otolaryngol Head and Neck Surg $119: 517-520,1993$.

6) Kelley DJ, Spiro RH : Management of the neck in parotid carcinoma. Am J Surg 172: 695-697, 1996.

7) Seifert G, Brocheriou C, Cardesa A, Eveson JW: WHO International histological classification of tumours. - Tentative histological classification of salivary gland tumours-. Path Res Pract 186: 555$581,1990$.

8) Sobin LH, Wittekind Ch: TNM Classification of Malignant Tumours. -UICC international union against cancer一. Fifth edition, 金原出版：43-46頁, 1997.

9) Robbins KT, Medina JE, Wolfe GT, Levine PA, Sessions RB, et al: Standardizing neck dissection terminology. -Official report of the academy's committee for head and neck surgery and oncology--. Arch Otolaryngol Head Neck Surg 117 : 601-605, 1991.

10）石毛俊行，金子敏郎：大唾液腺癌一全国1418例の検討と 予後一。癌治 $27: 1890-1895 ， 1992$.

11) Spiro RH : Salivary neoplasms : overview of a 35-year experience with 2807 patients. Head Neck Surg 8: 177-184, 1986.

12) O'brien CJ, Soong S-J, Herrera GA, Urist MM, Maddox WA : Malignant salivary tumors. - Analysis of prognostic factors and survival-. Head Neck Surg 9 : 82-92, 1986.

13）村上泰, 猪忠彦，堀内正敏，猪狩武詔，大築淳一， 他: 耳下腺腫煌70症例の治療経験。耳喉 48: 589-602, 1976.

14) Fu KK, Leibel SA, Levine ML, Friedlander LM, Boles $R$, et al: Carcinoma of the major and minor salivary glands. -Analysis of treatment results and sites and causes of failures. Cancer $40: 2882-2890,1977$.

15) Jackson GL, Luna MA, Byers RM : Results of surgery alone and surgery combined with postoperative radio. 
therapy in the treatment of cancer of the parotid gland. Am J Surg 146: 497-500, 1983.

16) Ball ABS, Fish $S$, Thomas JM: Malignant epithelial parotid tumours: a rational treatment policy. $\mathrm{Br} \mathrm{J}$ Surg $82: 621-623,1995$.

17）奥田 稔, 坂口幸作：耳下腺腫演の諮断と治療，耳鼻臨 床 $79: 867-879,1986$.

18）武藤博之, 沼田 勉, 永田博史, 今野昭義：唾液腺の悪 性腫場. JOHNS 15：1901-1906, 1999.

19）河田了: 唾液腺腫瘍の穿刺吸引紐胞診. JOHNS 15: 1887-1890, 1999.

20) Stewart CJR, Mackenzie K, Mcgarry GW, Mowat A : Fine-needle aspiration cytology of salivary gland: A review of 341 cases. Diagn Cytopathol $22: 139-146$, 2000.

21) Cajulis RF, Gokaslan ST, Yu GH, Frias-Hidregi D:
Fine needle aspiration biopsy of the salivary gland: A five-year experience with emphasis on diagnostic pitfalls. Acta cytol 41 : 1412-1420, 1997.

22) Ward MJ, Levine PA : Salivary gland tumors. Essentials of head and neck oncology, ed. by Close LG, Larson DL, Shah JP. Thieme: pp146-157, 1998.

本研究において切除標本の再検鏡およびその病理組織学的 検愘につき多大なるご指導，ご尽力を頂戴した山本智理子先 生, 柳澤昭夫先生に深く感謝申し上げます。 なお本論文の一部は第11回日本頭頸部外科学会において発 表した。

(2001年 9 月 12 日受稿 2002 年 1 月11日受理 急載) 別刷請求先 $\bar{T} 170-8455$ 東京都豊島区上池袋 1-37-1 癌研究会附属病院頭頸科 別府 武

\title{
Strategy of Neck Dissection in Parotid Cancer
}

\author{
Takeshi Beppu M.D., Shin-etsu Kamata M.D., Kazuyoshi Kawabata M.D. \\ Tomohiko Nigauri M.D., Katsufumi Hoki M.D., Hiroki Mitani M.D. \\ and Seiichi Yoshimoto M.D. \\ Division of Head and Neck, Cancer Institute Hospital, Tokyo
}

\begin{abstract}
We conducted definitive surgery on 45 patients with untreated primary parotid cancer from 1975 to 1995 , and evaluated methods of neck dissection and results of treatment. All 14 with clinical neck lymph node metastasis underwent ipsilateral radical neck dissection and only 1 developed neck lymph node recurrence at the peripheral dissected site. Of 31 patients without clinical neck lymph node metastasis, 27 of 19 of 36 with high-grade malignancy and 12 of 24 with T3 or T4 did not undergo prophylactic neck dissection and developed latent neck lymph node metastasis in 2 cases $(7.4 \%)$. Whereas in most cases we achieved good control of the primary site but neck lymph node recurrences occurred, recurrent sites were observed all around the ipsilateral neck and prognosis were very poor if neck dissection was conducted as secondary treatment. Although histopathological diagnosis was considered feasible for predicting occult neck lymph node metastasis, correct diagnostic with fine needle aspiration cytology revealed only $21.8 \%$. Pathological positive lymph nodes in 15 patients who underwent neck dissection were detected all over (level I to V) the ipsilateral neck and the recurrent positive rate at level II was $100 \%$. Based on the above results, we conclude that (1) in cases with neck lymph node metastasis in preoperative evaluation, ipsilateral radical neck dissection is mandated, and (2) in cases without neck lymph node metastasis, prophylactic neck dissection is not usually needed. When pathological results of frozen section from intraoperative jugulodigastric nodal sampling are positive, ipsilateral radical neck dissection is mandated.
\end{abstract}

Keywords : parotid cancer, neck dissection, prophylactic neck dissection, jugulodigastric node

J Otolaryngol Jpn 105 : 178-187, 2002 